\section{UK scientists must take lead in steering inevitable changes}

\section{London}

TRADITIONAL methods of organizing and financing British academic science can no longer support a system that has ceased to expand, and the scientists themselves should play a significant role in arriving at alternative schemes. Such were the two chief conclusions from a conference last week organized by the British Association for the Advancement of Science and aimed at prodding Britain's research community into having some input in determining its own fate. The title of the conference, 'Managing Science in a Steady State', was taken from a report of the Science Policy Research Group, an independent unit set up and supported by the research councils.

The essential argument of the report's author, John Ziman, is that because further expansion of scientific activity will be limited by economic and political considerations, a structure and management system must be developed that will allow adjustment to change within a constant envelope of resources, while being expected to serve the nation more efficiently and account more directly for costs. "The traditional academic organization of basic science evolved under conditions of expansion", Ziman told last week's meeting. "There is no way back to traditional academic arrangements for science. To attempt it would be trying to kick history in the face and that would really be the end of British academic science."

While there was general consensus on Ziman's analysis, suggestions about how analysis. biology programme. to arrive at solutions were more contentious. John Irvine, of the Science Policy Research Unit at Sussex University, was politely if not enthusiastically received for his contribution on the growing validity and acceptance of research evaluation techniques, including bibliometric

Funding agencies required a change in philosophy, Irvine argued, from regarding assessment techniques as post-hoc auditing to accepting them as "an integral part of the research management system". Inevitably, the discussion turned to the sensitive topic of the subject review programme currently being carried out by the University Grants Committee. With the earth sciences review now complete, physics and chemistry are being examined. K. Edwards, of the University of Leicester, pointed out that the outcome of previous reviews is likely to have an increasingly marked influence on successive reviews. An institution whose chemistry and physics departments had been forced to close would be unlikely to be able to support a

Given that the government is believed to be formulating proposals for the future shape of academic science and is expected to make an announcement later in the year, last week's meeting (with some 150 delegates, including several from the Cabinet Office) could turn out to be the last major forum for debate before major decisions are taken. If the scientists want to have a say, they should act quickly.

Simon Hadlington

\section{Who will lead human genome project?}

\section{Washington}

Controversy over who will be the lead agency in the human genome project erupted again last week as James Wyngaarden from the National Institutes of Health (NIH) and David Nelson of the Department of Energy (DOE) testified before a subcommittee of the US House of Representatives Committee on Energy and Commerce.

Questions posed by the subcommittee followed the line taken by the Office of Technology Assessment's report on the project (see Nature 332,$769 ; 1988$ ) and indicated that NIH and DOE will share in leadership. That flies in the face of advice given by the National Research Council, which specified the need for a lead agency in order to reduce the time and money spent on coordination between organizations.

During the hearing, DOE indicated their desire to share in the project rather than take control while NIH leant more towards establishing a single lead agency. Both organizations are very committed to the project but others will be involved. The National Science Foundation could be a source of revenue for instrumentation development.

Legislation to decide leadership could materialize from the Committee on Energy and Commerce after requested figures on budget breakdowns in the area of technology development arrive from the DOE. In the Senate there is related legislation in the form of a bill which carries a provision for the development of a National Advisory Panel on the Human Genome, and it is hoped that the bill will be passed through the Senate by the end of May. With the multitude of issues facing the 100th Congress, though, this is unlikely.

Elizabeth Ebbert
Sweet words on acid rain

\section{Washington}

Canadian Prime Minister Brian Mulroney ended his official visit to the United States with a promise from US President Ronald Reagan that an agreement to reduce acid rain would be "taken up as a matter of priority". Although Mulroney described Reagan's words as "encouraging", the prospects for a rapid change in US policy still seem slim.

Acid rain is the biggest cause of friction between the two nations. The Canadian side argues that more than half and, in places, as much as seventy per cent of the acid rain falling on eastern Canada comes from the burning of fossil fuels in the United States.

Mulroney presented Reagan with an eight-point proposal for an acid rain treaty. But the reaction from Reagan appeared similar to that given in April 1987 when he addressed the Canadian parliament and promised to "consider the Prime Minister's proposal for a bilateral accord on acid rain". No progress has been reported since then. At a press conference after his final meeting with Reagan, Mulroney answered complaints that he had obtained no clear commitment to reduce acid rain by saying "What do you do? Do you declare war? Do you interrupt relations? Or do you actively work to persuade Americans?". Mulroney believes that although "Canada has been disappointed before', an acid rain treaty between the United States and Canada will come "as surely as summer follows spring'.

Canada has acted to remove its own sources of acid rain with a control programme that will reduce sulphur dioxide emissions in eastern Canada to half of 1980 levels by 1994 .

Mulroney's visit coincided with the release of a new report from the Washington-based Environmental Defense Fund showing that nitrates deposited in acid rain are a major soure of pollution to eastern US coastal waters. Nitrates cause algal blooms which reduce light and oxygen levels.

US power companies-the major consumers of fossil fuels-continue to argue through their association, the Edison Electric Institute, that "rain acidity at current levels does not threaten the environment", They estimate that the cost of a major reduction in sulphur and nitrate emission would be a prohibitive $\$ 6,200$ million annually. Instead, they argue that they should be left to invest in new clean coal technologies which could be ready for the late 1990 s when many of the current plants will be due for replacement. 